\title{
Ceramah Interaktif Menghadapi Menopause pada Ibu-Ibu Anggota Pengajian Iqro' RT 14 Maguwo Desa Banguntapan
}

\author{
Nining Tunggal Sri Sunarti ${ }^{1}$, Winarsih ${ }^{2}$ \\ ${ }^{1,2}$ Program Studi DIII Kebidanan Sekolah Tinggi Ilmu Kesehatan AKBIDYO \\ Email: niningtunggal25@gmail.com ${ }^{1}$,winarsihakbidyo@gmail.com²
}

\begin{abstract}
ABSTRAK Wanita menopause di Daerah Istimewa Yogyakarta tahun 2015 sudah mencapai 3,9 ribu jiwa $(10,73 \%)$ dari jumlah penduduk DIY. Di Kabupaten Bantul penduduk perempuan mencapai 30,889 juta penduduk. Lama hidup seseorang menggambarkan derajat kesehatan. Seorang perempuan jika memiliki umur panjang pasti mengalami menopause yang sebagian besar disertai dengan berbagai masalah. Pengetahuan sangat penting bagi seorang perempuan dalam mengahadapi menopause. Beberapa hasil penelitian menunjukkan ada hubungan pengetahuan ibu usia premenopause tentang menopause dengan kesiapan menghadapi masa menopause. Pengetahuan tentang menopause memiliki hubungan dengan kesiapan ibu dalam menghadapi menopause. Beberapa penelitian juga menunjukkan adanya hubungan antara pengetahuan dengan kesiapan seorang perempuan dalam menghadapi menopause. Penelitian pada perempuan menopause menunjukkan bahwa sikap perempuan terhadap keluhan masa menopause masih kurang baik (55\%). Kelompok pengajian Iqro' 'di RT 14 Maguwo sebagian besar merupakan ibu-ibu yang masuk dalam masa pre menopause. Perlu adanya pemberian pengetahuan kepada ibu-ibu ini untuk meningkatkan pengetahuan tentang menopause, sehingga ibu-ibu siap menghadapinya dengan rasa bahagia. Metode yang digunakan ceramah dan tanya jawab. Sasaran ibu-ibu anggota pengajian Iqro' RT 14 dilaksanakan di Balai RT dengan sasaran ibu-ibu pre menopause sebanyak 26 orang pada hari sabtu, 12 Desember 2020. Peningkatan pengetahuan tentang menopause pada ibu-ibu anggota Pengajian Iqro' RT 14 Maguwo Desa Banguntapan Kecamatan Banguntapan Kabupaten Bantul meningkat setelah mengikuti ceramah hal ini dapat dilihat pada hasil pre tes yang menunjukkan pengetahuan baik sebanyak $19,2 \%$ meningkat menjadi $50 \%$ pada saat post tes. Selama proses ceramah peserta sangat antusias dan aktif bertanya, sehingga bisa bebagi cerita dan pengalaman.
\end{abstract}

Kata kunci : Ceramah interaktif ; Menopause.

ABSTRACT Menopausal women in the Special Region of Yogyakarta in 2015 had reached 3.9 thousand people (10.73\%) of the total population of DIY. In Bantul Regency, the female population reaches 30,889 million people. The length of a person's life describes the degree of health. If a woman has a long life, she must experience menopause, most of which are accompanied by various problems. Knowledge is very important for a woman in dealing with menopause. Some research results show that there is a relationship between the knowledge of premenopausal mothers about menopause and their readiness to face menopause. Knowledge about menopause has a relationship with the mother's readiness to 
face menopause. Several studies have also shown a relationship between knowledge and a woman's readiness to face menopause. Research on menopausal women shows that women's attitudes towards menopause complaints are still not good (55\%). The Iqro' recitation group in RT 14 Maguwo are mostly mothers who are in the pre-menopausal period. It is necessary to provide knowledge to these mothers to increase knowledge about menopause, so that mothers are ready to face it with a sense of happiness. The method used is lecture and question and answer. The target of the Iqro' RT 14 recitation members was held at the RT Hall with the target of 26 pre-menopausal mothers on Saturday, December 12, 2020. Increased knowledge about menopause among women members of the Iqro' Recitation of RT 14 Maguwo, Banguntapan Village, Banguntapan District, Bantul Regency, increased after attending the lecture, this can be seen in the pre test results which showed good knowledge of $19.2 \%$ increased to $50 \%$ at the time of post test. During the lecture process the participants were very enthusiastic and actively asked questions, so they could share stories and experiences.

Keywords: Interactive lectures; Menopause

\section{Pendahuluan}

Jumlah perempuan di seluruh dunia yang memasuki masa menopause pada tahun 2030 yang akan datang di perkirakan mencapai 1,2 milyar orang [1]. Pada tahun 2025 sebanyak 60 juta perempuan di Indonesia akan mengalami menopause. Pada tahun 2016, 7,4 \% dari total populasi yang ada atau sekitar 14 juta perempuan yang mengalami menopause. Perkiraan umur rata-rata usia manopause di Indonesia adalah 48 tahun [2]. Berdasarkan data Badan Pusat Statistik pada tahun 2017, jumlah penduduk perempuan di Daerah Istimewa Yogyakarta adalah 1.811.128 jiwa dengan jumlah penduduk perempuan menopause di tahun 2017 sudah mencapai 3,9 ribu jiwa $(10,73 \%)$ dari jumlah penduduk DIY[3].

Perempuan menopause di Daerah Istimewa Yogyakarta tahun 2015 sudah mencapai 3,9 ribu jiwa (10,73\%) dari jumlah penduduk DIY [4]. Di Kabupaten Bantul penduduk perempuan mencapai 30,889 juta penduduk. Sedangkan untuk perempuan yang memasuki usia menopause yaitu pada usia 40- 44 tahun terdapat 2,506 juta penduduk, usia 45-49 tahun mencapai 2411 juta penduduk dan untuk usia 50-54 tahun mencapai 1920 juta penduduk [5].

Angka Harapan Hidup (AHH) merupakan salah satu indikator Indeks Pembangunan Manusia (IPM). Badan Pusat Statistik menunjukkan Angka harapan hidup di Indonesia pada tahun 2018 adalah 69.30 Tahun naik di tahun 2019 menjadi 73,33 tahun, sedangkan AHH Daerah Istimewa Yogyakarta (DIY) pada tahun 2019 adalah 74.92 tahun lebih tinggi dari data nasional [6]. DIY juga memiliki jumlah lansia yang lebih banyak dibandingkan dengan propinsi lain, hal ini menunjukkan bahwa DIY merupakan propinsi dengan populasi penduduk tua yang tinggi. Kesehatan merupakan kebutuhan pokok bagi seluruh lapisan masyarakat. menurut World Health Organitation (WHO) sehat yaitu keadaan sejahtera secara fisik, mental dan sosial yang memungkinkan individu hidup secara produktif baik dalam aspek sosial maupun aspek ekonomi. Undang-undang No 36 Tahun 2009 menjelaskan bahwa setiap orang berhak atas kesehatan. Dalam hal ini, Angka Harapan Hidup merupakan alat untukmelakukan evaluasi kinerja dari pemerintah dalam mensejahterakan penduduk pada umumnya, dan derajat kesehatan pada khususnya[7]. 
Lama hidup seseorang menggambarkan derajat kesehatan. Seorang perempuan jika memiliki umur panjang pasti mengalami menopause yang sebagian besar disertai dengan berbagai masalah. Menanggulangi hal tersebut dengan mewujudkan rasa bahagia. Individu yang bahagia keluarga akan bahagia, keluarga bahagia masyarakatpun menjadi bahagia. Salah satu mewujudkan kebahagiaan itu adalah dengan adanya pengetahuan yang tinggi bagi perempuan tentang dirinya. Perlu pengetahuan bagi para perempuan tentang menopause dan bagaimana menangani masalah yang menyertainya.

Tabel 1. Angka harapan Hidup Kabupaten/kota di D.I. Yogyakarta Tahun 2014-2018

\begin{tabular}{|lccccc} 
& & \multicolumn{4}{c}{ Indeks Pembangunan Manusia } \\
Kabupaten/Kota & & \multicolumn{4}{c}{ Angka Harapan Hidup (Tahun) } \\
\cline { 2 - 6 } & $\mathbf{2 0 1 4}$ & $\mathbf{2 0 1 5}$ & $\mathbf{2 0 1 6}$ & $\mathbf{2 0 1 7}$ & $\mathbf{2 0 1 8}$ \\
\hline Kulonprogo & 74.50 & 74.68 & 74.71 & 74.74 & $\mathbf{7 4 . 8 2}$ \\
\hline Bantul & 73.24 & 73.44 & 73.50 & 73.56 & $\mathbf{7 3 . 6 6}$ \\
\hline Gunung Kidul & 73.39 & 73.69 & 73.76 & 73.82 & $\mathbf{7 3 . 9 2}$ \\
\hline Sleman & 74.47 & 74.57 & 74.60 & 74.63 & $\mathbf{7 4 . 6 9}$ \\
\hline Yogyakarta & 74.05 & 74.25 & 74.30 & 74.35 & $\mathbf{7 4 . 4 5}$ \\
\hline D.I. Yogyakarta & $\mathbf{7 4 . 5 0}$ & $\mathbf{7 4 . 6 8}$ & $\mathbf{7 4 . 7 1}$ & $\mathbf{7 4 . 7 4}$ & $\mathbf{7 4 . 8 2}$ \\
\hline
\end{tabular}

Sumber : BPS 2019

Tabel di atas menunjukkan bahwa Angka harapan hidup di lima kabupaten kota yang berada di Provinsi Daerah Istimewa Yogyakarta dari tahun 2014-2018 mengalami peningkatan dari tahun ke tahun. Bantul memiliki angka harapan hidup yang rendah dibandikan kabupaten/kota lain, sedangkan Kulonprogo memiliki angka harapan hidup yang paling tinggi.

Pengetahuan sangat penting bagi seorang perempuan dalam mengahadapi menopause. Ada hubungan pengetahuan ibu usia premenopause tentang menopause dengan kesiapan menghadapi masa menopause [8]. Pengetahuan tentang menopause memiliki hubungan dengan kesiapan ibu dalam menghadapi menopause[9]. Penelitian lain juga menunjukkan adanya hubungan antara pengetahuan dengan kesiapan seorang perempuan dalam menghadapi menopause[10]. Perempuan memiliki sikap terhadap keluhan masa menopause masih kurang baik (55\%)[11].

Mengingat besarnya dampak yang diakibatkan dari menopause sehingga perlunya upaya dalam meningkatkan pengetahuan ibu sehingga ibu dapat bersikap positif dalam menghadapi masa premenopause. Pengetahuan untuk perempuan pre menopause bisa didapatkan dengan berbagai cara salah satunya dengan memberikan ceramah kepada ibu-ibu pre menoupause. Ceramah merupakan salah satu cara yang efektif untuk meningkatkan pengetahuan.

Kelompok Pengajian Iqro' di RT 14 Maguwo sebagian besar merupakan ibu-ibu yang masuk dalam masa pre menopause. Perlu adanya pemberian pengetahuan kepada ibu-ibu ini untuk meningkatkan pengetahuan tentang menopause, sehingga ibu-ibu siap menghadapinya dengan rasa bahagia. Pemberian pengetahuan yang mudah dan biayanya murah adalah dengan metode ceramah.

Berdasarkan latar belakang di atas perlu adanya pengabdian masyarakat tentang ceramah interaktif menghadapi menopause pada ibu-ibu anggota Pengajian Iqro' RT 14 Maguwo Desa Banguntapan Kecamatan Banguntapan Kabupaten Bantul. 


\section{Metode}

Metode yang digunakan dalam penerapan IPTEKS ini adalah melakukan ceramah dan tanya jawab. Sasaran adalah ibu - ibu Penganjian Iqro' RT 14 Maguwo Desa Banguntapan dengan jumlah 26 peserta. yang dilaksanakan pada hari sabtu, 12 Desember 2020. Pengetahuan Ibu-ibu tentang menopause :

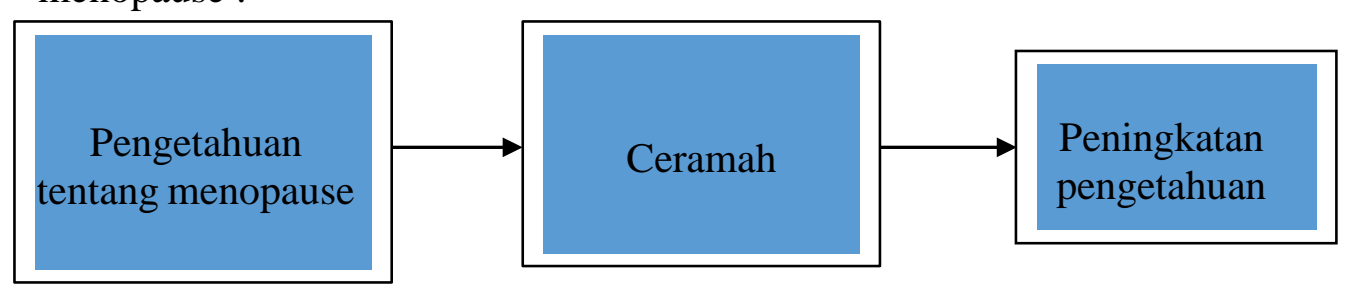

\section{Hasil dan Pembahasan}

Pengabdian kepada masyarakat ini dilaksanakan di Balai RT 14 Maguwo dengan sasaran ibu-ibu pre menopause pada hari sabtu, 12 Desember 2020. Peserta yangmengikuti sebanyak 26 orang. Karakteristik peserta adalah sebagai berikut :

Tabel 3. Karakteristik peserta berdasarkan umur

\begin{tabular}{|c|c|c|c|}
\hline No & Umur & Jumlah & $\begin{array}{c}\text { Persentase } \\
(\%)\end{array}$ \\
\hline 1. & $<40$ tahun & 2 & 7,7 \\
\hline 2. & 40-50 tahun & 15 & 57,7 \\
\hline 3. & $>50$ tahun & 9 & 34,6 \\
\hline Total & & 26 & 100 \\
\hline
\end{tabular}

Tabel 3. di atas menunjukan karakteristik peserta berdasarkan umur. Peserta terbanyak berumur 40-50 tahun yaitu 57,7\% dan paling sedikit berusia kurang dari 40 tahun sebanyak $7,7 \%$.

Tabel 4. Karakteristik peserta berdasarkan pendidikan

\begin{tabular}{llccc}
\hline No & & Pendidikan & Jumlah & $\begin{array}{c}\text { Persentase } \\
(\boldsymbol{\%})\end{array}$ \\
\hline 1. & SD & 2 & $\mathbf{7 , 7}$ \\
\hline 2. & SMP & 1 & $\mathbf{3 , 8}$ \\
\hline 3. & SMA & 18 & $\mathbf{6 9 . 3}$ \\
\hline 4. & Pendidikan Tinggi & 5 & $\mathbf{1 9 , 2}$ \\
\hline \multicolumn{2}{l}{ Total } & $\mathbf{2 6}$ & $\mathbf{1 0 0}$ \\
\hline
\end{tabular}

Tabel 4. Di atas menunjukkan karakteristik peserta berdasarkan pendidikan. Peserta terbanyak berpendidikan SMA yaitu 69,3\%. Pendidikan peserta paling sedikit adalah SMP yaitu sebanyak 3,8\% namun masih ada peserta berpendidikan SD sebanyak 7,7\%. 


\begin{tabular}{|c|c|c|c|}
\hline No & Pekerjaan & Jumlah & $\begin{array}{c}\text { Persentase } \\
(\%)\end{array}$ \\
\hline 1. & Ibu Rumah Tangga & 15 & 57.7 \\
\hline 2. & Petani & 1 & 3,8 \\
\hline 3. & Pedagang & 4 & 15,4 \\
\hline 4. & Karyawan & 6 & 23,1 \\
\hline \multicolumn{2}{|c|}{ Total } & 26 & 100 \\
\hline
\end{tabular}

Tabel 5. Meunjukkan tentang karakteristik peserta berdasarkan pekerjaan. Pekerjaan peserta terbanyak adalah ibu rumah tangga sebanyak $57,7 \%$ dan pekerjaan peserta paling sedikit adalah petani sebanyak 3,8\%

Tabel. 6 Pengetahuan peserta sebelum dan sesudah ceramah

\begin{tabular}{crcccc}
\hline No & Keterangan & \multicolumn{2}{c}{ Pre Tes } & \multicolumn{2}{c}{ Post Tes } \\
\cline { 3 - 6 } & & Jumlah & $\begin{array}{c}\text { Persen } \\
(\mathbf{\%})\end{array}$ & Jumlah & $\begin{array}{c}\text { Persen } \\
(\mathbf{\%})\end{array}$ \\
\hline 1. & Baik & 5 & 19.2 & 13 & $\mathbf{5 0}$ \\
\hline 2. & Cukup & 9 & 34,6 & 11 & $\mathbf{4 2 . 3}$ \\
\hline 3. & Kurang & 12 & 46,2 & 2 & $\mathbf{7 , 7}$ \\
\hline \multicolumn{2}{l}{ Total } & $\mathbf{2 6}$ & $\mathbf{1 0 0}$ & $\mathbf{2 6}$ & $\mathbf{1 0 0}$ \\
\hline
\end{tabular}

Tabel 6. Menunjukkan pengetahuan peserta sebelum dan sesudah mengikuti ceramah. Dapat dilihat bahwa terjadi peningkatan pengetahuan peserta pada saat pre tes peserta dengan pengetahuan baik sebanyak 19,2\% meningkat menjadi 50\% pada saat post tes.

Peserta pengabdian masyarakat ini memiliki rentang umur 40-50 tahun yang merupakan masa pre menopause. Masa premenopause merupakan suatu fase alamiah yang dialami oleh setiap perempuan yang biasanya terjadi di atas usia 40 tahun. Masa ini sudah masuk pada fase klimakterium, dimana pada umur ini banyak keluhan yang dirasakan akibat dari perubahan fisik dan psikologis. Umur seorang perempuan memasuki masa premenopause antara 40-49 tahun. Dimana saat seorang perempuan memasuki usia pertengahan empat puluhan, fungsi ovarium akan mulai menurun, sehingga dapat menyebabkan kadar hormon dalam tubuh tidak seimbang, yang akhirnya menyebabkan berbagai gangguan[12].

Umur seseorang juga dapat berpengaruh terhadap kesiapan seseorang dalam menghadapi menopause. Umur berkaitan dengan bertambahnya pengalaman seseorang, dimana pengalaman tersebut akan meningkatkan pengetahuan dankematangan seseorang dalam menghadapi masalah-masalah yang terjadi dalam kehidupan. Ada perempuan yang merasa senang dan bahagia menempuh umur setengah baya dan peristiwa menopause. Keadaan ini dikarenakan wanita yang sudah maupun menjelang menopause mempunyai anggapan bahwa menopause merupakan peristiwa alami yang akan dialami oleh semua perempuan, sehingga mereka menganggap sebagai hal biasa. Semakin bertambahnya umur seseorang, pengalamannya akan bertambah sehingga akan lebih siap dalam menghadapi menopause [13]. 
Umur juga mempengaruhi tingkat pengetahuan seseorang. Pengalaman merupakan suatu cara menambah pengetahuan seseorang tentang suatu hal. Semakin tua umur seseorang, maka pengalamannya akan bertambah, sehingga meningkatkan pengetahuannya tentang suatu objek tertentu. Umur merupakan variabel yang selalu diperhatikan dalam penelitian epidemiologi yang merupakan salah satu hal yang dapat mempengaruhi pengetahuan. Umur atau usia perempuan berhubungan dengan tingkat pengetahuan tentang klimakterium[14].

Tingkat pendidikan sangat mempengaruhi tingkat pengetahuan. Semakin tinggi pendidikan seseorang, maka semakin tinggi daya serapnya terhadap informasi yang diperolehnya sehingga informasi dapat dipahami dengan baik. Sebaliknya, semakin rendah tingkat pendidikan, maka pola pikirnya juga semakin rendah sehingga daya serap terhadap informasi juga menjadi kurang. Hal ini sesuai dengan teori yang menyatakan bahwa tingkat pendidikan merupakan salah satu faktor yang mempengaruhi pengetahuan, selain itu faktor pengalaman dan informasi akan menambah pengetahuan tentang sesuatu yang bersifat nonformal[15]. Perempuan yang berpendidikan akan memiliki pengetahuan kesehatan yang lebih baik. Pendapat lain mengatakan ada hubungan tingkat pendidikan terhadap kesiapan menghadapi menopause [16].

Sebagian besar peserta memiliki pekerjaan sebagai Ibu Rumah Tangga (IRT). Pekerjaan yang dijalani oleh seorang perempuan premenopause berhubungan dengan banyaknya kesempatan untuk bersosialisasi dan menyerap informasi kesehatan. Perempuan yang bekerja, mereka tidak sempat memikirkan gangguan-gangguan menjelang menopause karena kesibukannya. Berbeda dengan ibu rumah tangga, mereka memiliki banyak waktu setelah selesai melakukan pekerjaan, sehingga IRT memiliki waktu luang untuk memikirkan gangguan-gangguan menjelang menopause, akan tetapi hal tersebut tergantung dari individu itu sendiri, terbukti ada perempuan yang merasa senang dan bahagia menempuh umur setengah baya dan peristiwa menopause.

Perempuan yang tetap berusaha hidup aktif akan menekan gangguan menjelang menopause seperti memperlambat osteoporosis, insomnia, penyakit jantung, serta mencegah hot flushes[17]. Pendapat mengatakan wanita yang bekerja akan lebih siap dan mampu menjalani masa menopause dengan baik dibandingkan dengan wanita yang tidak bekerja atau hanya sebagai ibu rumah tangga, dikarenakan pada wanita yang bekerja sudah terbiasa dengan aktivitas fisik dan masalah-masalah yang sering dihadapi dalam pekerjaan, sehingga ketakutan terhadap menopause lebih berkurang dan dianggap bukan masalah yang sulit untuk dihadapi[16].

Perempuan bekerja cenderung memiliki keadaan social ekonomi yang lebih baikkarena mampu mendapatkan penghasilan sendiri. Pekerjaan sering dikaitkan dengan keadaan sosial ekonomi. Keadaan sosial ekonomi dapat mempengaruhi faktor pendidikan, fisik, dan kesehatan. Perempuan yang berasal dari golongan ekonomi rendah mampu beradaptasi dengan baik dan cenderung pasrah saat mengalami menopause. Budaya sangatberpengaruh terhadap cara seorang perempuan dalam menanggapi proses berhentinya haid.

Perempuan Indonesia yang mayoritas adalah muslimah, umumnya dapat menerima masa menopause dengan baik. Masalah yang dihadapi tidak hanya pada perempuan menopause tetapi juga dialami perempuan premenopause dimana tanggapan-tanggapan masyarakat tentang menopause akhir-akhir ini semakin meningkat [18] Kondisi kesehatan seseorang dapat 
mempengaruhi kondisi psikologis, misalnya pada penderita penyakit kronis. Hal itu dapat terjadi pada perempuan menjelang menopause, karena di sana terjadi masa peralihan atau perubahan- perubahan.

Pengetahuan menjadi hal yang penting dalam meningkatkan status kesehatan perempuan, perempuan yang mengetahui tentang menopause akan lebih mampu menghadapi menopause dengan baik. Faktor-faktor yang berhubungan dengan kesiapan menopause pada perempuan antara lain adalah tingkat pengetahuan yang berpengaruh terhadap besar kecilnya kesiapan ibu dalam menghadapi menopaus [18]. Ibu yang memiliki pengetahuan kesehatan lebih baik akan lebih siap dalam menghadapi masa menopause sehingga terjadi perubahan yang baik atau positif.

Pengetahuan yang baik membantu ibu memahami dan mempersiapkan dirinya menjalani menopause. Pengetahuan baik yang dimiliki responden akan mempengaruhi kesiapan dalam menghadapi masa menopause. Sedangkan responden yang berpengetahuan baik tetapi tidak memiliki kesiapan dikarenakan adanya rasa takut menghadapi masa menopause dan pengamalan yang berhubungan dengan umur. Responden yang berpengetahuan kurang baik tetapi memiliki kesiapan dikarenakan adanya informasi yang diperoleh tentang menopause[8].

Keberhasilan suatu penyuluhan kesehatan dalam hal ini menggunakan metode ceramah dipengaruhi oleh faktor penyuluh, sasaran dan proses penyuluhan. Faktor penyuluh, tentunya sangat penting seperti persiapan, penguasaan materi yang dijelaskan, penampilan, bahasa yang digunakan, intonasi suara serta teknik penyampaian materi jika hal ini menarik maka akan menyenangkan bagi peserta[19]. Faktor sasaran, contohnya tingkat pendidikan mempengaruhi daya serap materi, tingkat sosial ekonomi terlalu rendah sehingga tidak begitu memperhatikan pesan-pesan yang disampaikan karena lebih memikirkan kebutuhan y ang lebih mendesak, kepercayaan dan adat kebiasaan yang telah tertanam sehingga sulit untuk mengubahnya, kondisi lingkungan tempat tinggal sasaran yang tidak mungkin terjadi perubahan perilaku. Faktor yang ketiga adalah proses penyuluhan, misalnya waktu penyuluhan tidak sesuai dengan waktu yang diinginkan sasaran, tempat penyuluhan terlalu ramai atau dekat keramaian sehingga menggangu proses penyuluhan yang dilakukan, jumlah sasaran penyuluhan yang terlalu banyak, alat peraga yang kurang, metoda yang digunakan kurang tepat sehingga membosankan sasaran serta bahasa yang digunakan kurang dimengerti oleh sasaran. 


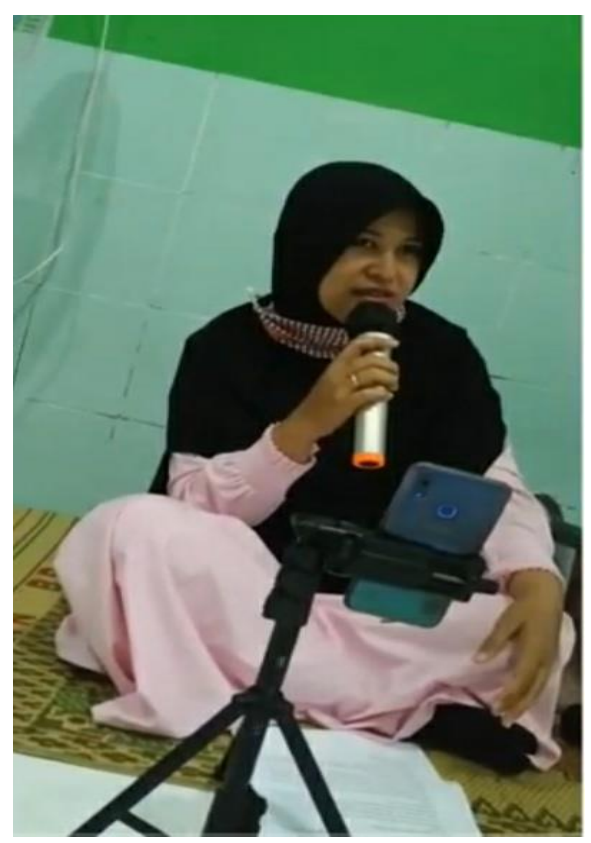

Gambar 1 . Dokumentasi 1 kegiatan ceramah pada ibu ibu menopause

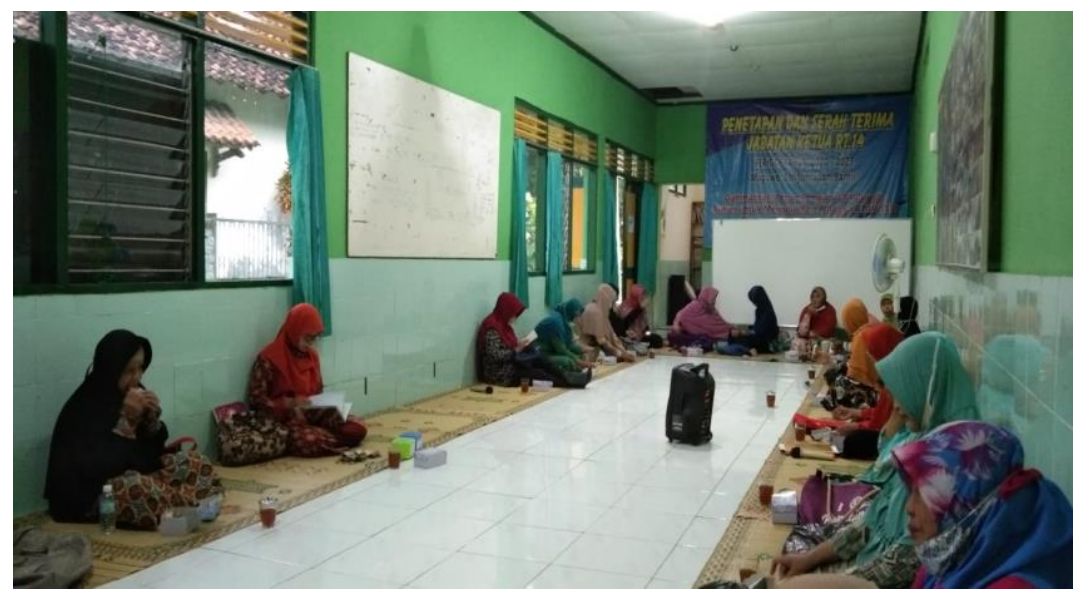

Gambar 2 . Dokumentasi 2 kegiatan ceramah pada ibu ibu menopause

\section{Kesimpulan}

Peningkatan pengetahuan tentang menopause pada ibu-ibu anggota Pengajian Iqro' RT 14 Maguwo Desa Banguntapan Kecamatan Banguntapan Kabupaten Bantul dapat dilaksanakan dengan menggunakan metode ceramah dan Tanyajawab. Pengetahuan peserta meningkat setelah mengikuti ceramah hal ini dapat dilihat pada hasil pre tes yang menunjukkan pengetahuan baik sebanyak $19,2 \%$ meningkat menjadi $50 \%$ pada saat post tes. Pengetahuan yang baik tentang menopause akan membantu perempuan menjalani setiap fase dalam hidupnya khususnya masa menopause. Saran Untuk peserta lebih aktif dalam Tanya jawab dan menyampaikan pengalaman hidupnya untuk bertukar pengalaman dengan peserta lain dan lebih banyak mengikuti ceramah kesehatan atau membaca artikel kesehatan untuk meningkatkan pengetahuan dan untuk pembicara dapat menggunakan metode lain dalam memberikan pendidikan kesehatan kepada perempuan khususnya pada usia premenopause seperti dengan diskusi interaktif dalam kelompok kecil untuk dapat memecahkan permasalahan yang dialami oleh para perempuan. 


\section{Ucapan terima kasih}

Puji syukur hanya penulis panjatkan kepada Allah SWT, yang telah melimpahkan rahmat dan ridha-Nya, sehingga Pengabdian Masyarakat ini terlaksana dengan baik. Pengabdian Masyarakat dengan judul " Ceramah Interaktif Menghadapi Menopause pada Ibu-ibu Anggota Pengajian Iqro' RT 14 Maguwo Desa Banguntapan Kecamatan Banguntapan Kabupaten Bantul" ini disusun untuk memenuhi Tri Darma Perguruan Tinggi Dosen Sekolah Tinggi Ilmu Kesehatan Akbidyo.

Dalam penyusunan Laporan ini, banyak mendapat arahan, saran, dan motivasi dari berbagai pihak, dan dalam kesempatan ini dengan segala kerendahan hati, Tim pengabdian mengucapkan terimakasih dan penghargaan yang tulus kepada:

1. Ibu Hj. Sri Suyatie, SH, M.Hum selaku Ketua Yayasan Bhakti Sosial

2. Bapak dr. Musinggih Djarot Roujani, Sp.KJ selaku Ketua Sekolah Tinggi Ilmu Kesehatan Akbdiyo

3. Ibu Dr. Fitriani Mediastuti, S.Si, M.Kes selaku Kepala BPPKM Ketua Sekolah Tinggi Ilmu Kesehatan Akbdiyo

4. Ketua Pengajian Iqro' RT 14 Maguwo Wonocatur yang telah memberikan ijin

5. Seluruh rekan dosen dan karyawan Sekolah Tinggi Ilmu Kesehatan Akbidyo yang telah memberikan dukungan.

Akhir kata, semoga Laporan pengabdian masyarakat ini dapat bermanfaat untuk pembaca. Semoga Allah SWT., Tuhan Yang Maha Kuasa memberikan rahmat, berkah dan ridha-Nya kepada semua pihak yang telah memberikan dukungan.

\section{Daftar Pustaka}

[1] WHO, "World health statistics 2014," 2014. [Daring]. Tersedia pada: http://www.who.int/gho/publications/world_health_statistics/2014/en/.

[2] Kementerian Kesehatan Republik Indonesia, Profil Kesehatan Indonesia 2016. 2016.

[3] Badan Pusat Statistik Kabupaten Bantul, "Kabupaten Bantul Dalam Angka Tahun 2017," Bantul, 2017. [Daring]. Tersedia pada: https://bantulkab.bps.go.id/publication/2017/08/14/e068a803ff4b2054367d 2404/kabupaten-bantul-dalam-angka-2017.html.

[4] Kementerian Kesehatan Republik Indonesia, "Riskesdas Dalam Angka Daerah Istimewa Yogyakarta Tahun 2013," 2013. [Daring]. Tersedia pada: https://www.pusat2.litbang.kemkes.go.id/wpcontent/uploads/2018/03/Riskesdas-Dalam-Angka-Prov-DIY.pdf.

[5] Badan Pusat Statistik DIY, "Provinsi Daerah Istimewa Yogyakarta Dalam Angka 2016," 2016. [Daring]. Tersedia pada: https://yogyakarta.bps.go.id/publication/download.html?nrbvfeve=MWQx NTg5NjA0OGZhYmQ1ZjdjNDhiZmY3\&xzmn=aHR0cHM6Ly95b2d5Y WthcnRhLmJwcy5nby5pZC9wdWJsaWNhdGlvbi8yMDE2LzA3LzE1LzF kMTU4OTYwNDhmYWJkNWY3YzQ4YmZmNy9wcm92aW5zaS1kaS1 5b2d5YWthenRhLWRhbGFtLWFuZ2thLTIwM.

[6] Bappeda DIY, "Dataku," 2020. http://bappeda.jogjaprov.go.id/dataku/survei.

[7] World Health Organization, "Physical Activity," 2017. [Daring]. Tersedia pada: http://www.who.int/mediacentre/factsheets/fs385/en.

[8] R. Novianti dan P. Yunita, "Hubungan Pengetahuan Ibu Usia Premenopouse Tentang Menopouse Dengan Kesiapan Menghadapi Masa 
Menopouse Di Puskesmas Sei Pancur Kota Batam tahun 2017," J. Kebidanan, vol. 9, no. 2, hal. 13-18, 2019.

[9] S. Kusumawati, "Hubungan Tingkat Pengetahuan Dengan Kesiapan Ibu Dalam Menghadapi Menopause Di Desa Berangas Timur Kab. Barito Kuala," J. Bidan Prada, vol. 10, no. 1, hal. 13-20, 2019, [Daring]. Tersedia pada: https://ojs.stikesylpp.ac.id/index.php/Prada/article/view/488.

[10] S. Sasrawita, "Hubungan Pengetahuan, Sikap Tentang Menopause Dengan Kesiapan Menghadapi Menopause Di Puskesmas Pekanbaru," J. Endur., vol. 2, no. 2, hal. 117, 2017, doi: 10.22216/jen.v2i2.1853.

[11] A. Arifarahmi, "Woman'S Attitude About Menopause Complaints At the Public Health Center Kebun Handil Jambi City," J. Akad. Baiturrahim Jambi, vol. 8, no. 1, hal. 107, 2019, doi: 10.36565/jab.v8i1.108.

[12] J. Rambulangi, "Tantangan , Harapan dan Pengobatan Alternatif dalam Meningkatkan Produktivitas dan Kualitas Hidup Wanita Menopause *," Indones. J. Obstet. Gynecol., vol. 30, no. 2, hal. 69-75, 2006, [Daring]. Tersedia pada: http://www.inajog.com/index.php/journal/article/view/13/81.

[13] S. Notoatmodjo, Pendidikan dan perilaku kesehatan. Jakarta: Rhineka Cipta, 2012.

[14] I. R. Budi dan Susilowati, "Hubungan Pengetahuan Tentang Menopause Dengan Tingkat Kesiapan Menjelang Menopause pada Ibu Premenopause," Universitas Diponegoro, 2017.

[15] Soekanto, Sosiologi Sebagai Suatu Pengantar. Jakarta: CV Rajawali, 2002.

[16] S. Wahyuni, Y. Yusrizal, dan W. Wardiati, "Faktor-Faktor Yang Mempengaruhi Kesiapan Wanita Usia 40-50 Tahun Dalam Menghadapi Menopause Di Kecamatan Langsa Timur Kota Langsa," Jukema (Jurnal Kesehat. Masy. Aceh), vol. 6, no. 1, hal. 4-12, 2020, doi: 10.37598/jukema.v6i1.795.

[17] Melani, Siapkan Diri Sebelum Menopause Datang. Jakarta: Puspa Suara, 2007.

[18] S. Prawirohardjo, Ilmu Kebidanan. Jakarta: PT Bina Pustaka Sarwono Prawirohardjo, 2014.

[19] E. U. Onong, Ilmu Komunikasi Teori Dan Praktek. Bandung: PT. Remaja Rosda Karya, 2003. 